\title{
PENINGKATAN KETERAMPILAN MENULIS KALIMAT BAHASA JERMAN SISWA MENGGUNAKAN MODEL PEMBELAJARAN COURSE REVIEW HORAY (CRH)
}

\author{
Astuti $^{1}$ dan Misnah Mannahali ${ }^{2}$ \\ Program Studi Pendidikan Bahasa Jerman, Fakultas Bahasa dan Sastra \\ Universitas Negeri Makassar \\ Email: astuti@gmail.com ${ }^{1}$
}

\begin{abstract}
ASBTRAK
Tujuan penelitian ini adalah untuk mengetahui peningkatan keterampilan menulis kalimat sederhana siswa melalui model pembelajaran Course Review Horay (CRH). Penelitian ini adalah penelitian tindakan kelas yang terdiri dari dua siklus. Teknik penumpulan data dalam penelitian tindakan kelas ini terdiri dari dua jenis, yaitu data kualitatif dan kuantitatif. Data kualitatif, yaitu data yang mendeskripsikan proses hasil belajar yang diperoleh melalui observasi. Sedangkan kuantitatif diperoleh dari hasil tes siklus I dan siklus II. Nilai rata-rata hasil tes siswa pada siklus I adalah 4,64 $(66,28 \%)$ dan pada siklus II diperoleh nilai rata - rata siswa 5,97 $(85,28 \%)$ Hal ini berarti bahwa keterampilan menulis kalimat sederhana bahasa Jerman siswa kelas X Bahasa dan Sastra 2 SMA Negeri 5 Bulukumba menggunakan model pembelajaran Course Review Horay $(\mathrm{CRH})$ mengalami peningkatan.
\end{abstract}

Kata Kunci: Keterampilan Menulis, Kalimat Sederhana, dan model pembelajaran Course Review Horay (CRH)

\section{ASBTRACT}

The purpose of this research is to know the improvement of the student's skill of writing simple sentence through Course Review Horay (CRH) learning model. This study is a classroom action research consisting of two cycles. Data collection techniques in this classroom action research consists of two types, namely qualitative and quantitative data. Qualitative data, namely data that describe the learning outcomes obtained through observation. While the quantitative results obtained from the test cycle I and cycle II. The average score of student test result in cycle I was $4.64(66.28 \%)$ and in cycle II the average score of students was 5.97 (85.28\%) This means that the student's skill of writing simple sentence using Course Review Horay (CRH) learning model has increased.

Keywords: Writing Skill, Simple Sentence, Course Review Learning Model (CRH)

\section{PENDAHULUAN}

Pembelajaran bahasa Jerman di SMA menekankan empat kompetensi dan dua aspek penunjang. Keempat aspek kompetensi tersebut saling berkaitan dan tidak dapat dipisahkan satu sama lainnya, saling mendukung, saling menunjang dan masingmasing memiliki kesulitan yang berbedabeda. Dari keempat aspek kompetensi berbahasa di atas, keterampilan menulis dijadikan objek dalam penelitian ini karena keterampilan menulis merupakan salah satu 
kompetensi berbahasa yang melibatkan berbagai keterampilan lain.

Keterampilan menulis meliputi kemampuan menyusun pikiran dan perasaan dengan menggunakan kata-kata dalam bentuk kalimat yang tepat, serta menyusunnya dalam suatu paragraf. Pada kenyataannya keterampilan menulis kurang disenangi dan kurang mendapat perhatian lebih dari siswa. Hal ini terjadi dikarenakan menulis merupakan keterampilan yang sukar dibandingkan dengan kompetensi berbahasa lainnya, sehingga upaya yang dapat dilakukan untuk membina, mengembangkan dan meningkatkan keterampilan menulis perlu dilakukan (Mantasiah dkk, 2017; Qalbi dkk, 2017)

Dari hasil observasi awal di SMA Negeri 5 Bulukumba kelas X Bahasa dan Sastra 2 yang merupakan objek dalam penelitian ini, di peroleh informasi bahwa siswa kesulitan menulis kalimat dalam bahasa Jerman karena kurangnya pengalaman siswa dalam pembelajaran menulis kalimat bahasa Jerman di Sekolah. Siswa juga kurang aktif saat proses pembelajaran berlangsung karena model pembelajaran yang digunakan guru pada saat proses pembelajaran kurang menarik. Untuk menghindari hal di atas diperlukan model pembelajaran yang dapat menciptakan suasana belajar yang menyenangkan, sehingga konsep dan materi yang disampaikan dapat dipahami dengan baik. Dengan demikian tujuan pembelajaran dapat tercapai.

Untuk mencapai tujuan pembelajaran di atas, selain menggunakan media yang tepat, model pembelajaran yang di gunakan pun harus menarik (Jufri, 2007; Jufri, 20170. Permainan (games) adalah salah satu model pembelajaran yang menarik dan dapat dilakukan di sekolah. Salah satu model pembelajaran permainan (games) yang dapat digunakan dalam pembelajaran keterampilan menulis adalah "Course Review Horay". Course Review Horay (CRH) merupakan model pembelajaran dengan menggunakan strategi games, apabila siswa dapat menjawab soal secara benar maka siswa tersebut diwajibkan meneriakan kata "hore" ataupun yel-yel yang disukai dan telah disepakati oleh kelompok maupun individu siswa itu sendiri.

Terdapat beberapa penelitian sebelumnya yang mengkaji berbagi metode ataupun model pembelajaran yang dapat digunakan untuk meningkatkan hasil belajar siswa (Romadloni dkk, 2017; Qudus \& Yusri, 2017; Yusri dkk, 2018). Salah satu penelitian yang fokus mengkaji tentang model CRH dilakukan oleh Sulistiyanti (2012) menyimpulkan bahwa terdapat pengaruh penggunaan model pembelajaran Course Review Horay (CRH) terhadap pencapaian kompetensi bekerja secara tim mata pelajaran pelayanan prima di kelas X Tata Busana SMK Negeri 2 Godean dengan pencapaian kompetensi siswa sebesar 10,24\%. Hal tersebut juga didukung oleh hasil penelitian lainnya yang dilakukan oleh Ruhiyat (2014: ii) menyimpulkan bahwa model pembelajaran Course Review Horay (CRH) efektif dalam meningkatkan penguasaan nomina bahasa Jerman siswa kelas XII IPA SMAN 12 Bandung, dengan persentase sebesar 7,97\%.

Hal ini sejalan dengan penelitian yang dilakukan oleh Amalia (2014:i) menyimpulkan bahwa penggunaan model pembelajaran Course Review Horay (CRH) pada mata pelajaran Matematika dapat meningkatkan hasil belajar siswa dengan nilai rata-rata pada siklus I diperoleh 85,34 sedangkan nilai rata-rata pada siklus II sebesar 91,89 dan ketuntasan belajar kelas untuk 
siklus I yaitu $86 \%$ dan meningkat pada siklus II yaitu $96 \%$.

\section{MODEL PEMBELAJARAN COURSE REVIEW HORAY (CRH)}

Fatmawati (2015: 30) mengemukakan bahwa "Course Review Horay (CRH) merupakan model pembelajaran yang menarik motivasi siswa dengan penggunaan nomor dan yel-yel dalam pembelajaran". Lebih lanjut Suprijono (2012: 129) menyatakan bahwa "Course Review Horay (CRH) merupakan model pembelajaran yang dapat melatih siswa untuk mencapai tujuan-tujuan hubungan sosial yang pada akhirnya mempengaruhi prestasi akademik siswa“. Taniredja (2011:110) mengemukakan bahwa "Course Review Horay (CRH) adalah model pembelajaran dikemas dalam bentuk permainan, dimana siswa yang mendapat tanda $(\checkmark)$ harus berteriak horay". Menurut Aqib (2015: 28 ) Course Review Horey merupakan suatu model pembelajaran dengan pengujian pemahaman menggunakan kotak yang diisi dengan nomor untuk menuliskan jawabannya, yang paling dulu mendapatkan tanda benar vertikal atau horisontal, atau diagonal langsung berteriak horey. Berdasarkan pendapat para ahli di atas dapat disimpulkan bahwa model pembelajaran Course Review Horay (CRH) adalah suatu model pembelajaran yang menyenangkan karena dikemas dalam bentuk games dan siswa yang menjawab benar harus berteriak horay.

Langkah-langkah model pembelajaran Course Review Horay (CRH) menurut Suprijono (2012: 129) yaitu: (1) Guru meyampaikan kompetensi yang ingin diacapai; (2) Guru mendemonstrasikan/ menyajikan materi; (3) Memberikan kesempatan siswa tanya jawab; (4) Menguji pemahaman, siswa disuruh membuat kotak 9/16/25 sesuai dengan kebutuhan dan tiap kotak diisi angka sesuai dengan selera masing-masing siswa; (5) Guru membaca soal secara acak dan sisiwa menulis jawaban di dalam kotak yang nomornya disebutkan guru dan langsung didiskusikan, kalau benar diisi tanda benar $(\sqrt{ })$ dan salah diisi tanda silang (x); (6) Siswa yang sudah mendapat tanda $(\sqrt{ })$ vertikal atau horizontal atau diagonal harus berteriak hore atau yel-yel lainnya; (7) Nilai siswa dihitung dari jawaban benar jumlah hore yang diperoleh; (8) Penutup.

Berdasarkan pendapat di atas, maka dapat disimpulkan langkah-langkah model pembelajaran Course Review Horay (CRH) yaitu:

1. Guru mendemonstrasikan atau menyajikan materi;

2. Memberi kesempatan siswa tanya jawab;

3. Siswa dibagi dalam beberapa kelompok;

4. Untuk menguji pemahaman siswa disuruh membuat kartu atau kotak sesuai dengan kebutuhan dan diisi dengan nomor yang ditentukan guru;

5. Guru membaca soal secara acak dan siswa menuliskan jawabannya didalam kotak yang nomornya disebutkan guru;

6. Kemudian guru dan siswa mendiskusikan soal yang telah diberikan tadi;

7. Siswa yang menjawab benar, siswa memberi tanda check list $(\sqrt{ })$ dan langsung berteriak horay atau menyanyikan yel-yel sesuai kesepakatan kelompok masingmasing.

8. Nilai dihitung dari jawaban benar dan jumlah horay yang diperoleh.

9. Guru memberikan reward pada kelompok yang memperoleh nilai tinggi atau yang banyak memperoleh horay. Selanjutnya setiap siswa membuat kalimat sederhana 
bahasa Jerman berdasarkan kata-kata yang terdapat dalam kotak.

Huda (dalam Revika 2016: 16) mengemukakan beberapa Kelebihan dan Kekurangan Model Pembelajaran Course Review Horay $(\mathrm{CRH})$ sebagai berikut:

\section{Kelebihan Model Pembelajaran Course Review Horay (CRH).}

1. Pembelajarannya menarik dan dapat mendorong siswa untuk dapat terjun kedalamnya.

2. Pembelajarannya tidak monoton karena diselingi dengan hiburan, sehingga suasana tidak menegangkan

3. Semangat belajar yang meningkat karena suasana pembelajaran berlangsung menyenangkan.

4. Skill kerjasama antarsiswa yang semakin terlatih.

\section{Kelemahan Model Pembelajaran Course Review Horay (CRH).}

1. Penyamarataan nilai antara siswa pasif dan aktif;

2. Adanya peluang untuk curang;

3. Beresiko mengganggu proses belajar mengajar kelas lain.

\section{METODE PENELITIAN}

Penelitian ini menggunakan model penelitian tindakan kelas (PTK) Classroom Action Research (CAR) yang dilakukan secara kolaborasi antara guru dan peserta didik secara langsung. Penelitian tindakan kelas merupakan suatu pencermatan terhadap kegiatan belajar berupa sebuah tindakan, yang sengaja dimunculkan dan terjadi dalam sebuah kelas secara bersama. Tindakan tersebut diberikan oleh guru atau dengan arahan guru yang dilakukan oleh peserta didik. (Arikunto: 2010)
Subjek penelitian ini adalah siswa kelas X Bahasa dan Sastra 2 SMA Negeri 5 Bulukumba tahun pelajaran 2016/2017 yang berjumlah 37 siswa, laki-laki terdiri 14 orang dan perempuan 23 orang. Penelitian ini dilakukan di SMA Negeri 5 Bulukumba yang beralamat di jalan So'larieng no. 1 Kecamatan Kajang, Kabupaten Bulukumba, Provinsi Sulawesi Selatan.

Penelitian ini disajikan dalam bentuk siklus. Penelitian dilakukan dalam dua siklus, yaitu siklus I dan siklus II. Masing-masing siklus terdiri atas empat tahap atau langkah. Langkah-langkah tersebut adalah 1) perencanaan, 2) tindakan, 3) pengamatan atau observasi, dan 4) refleksi. Penelitian ini dilaksanakan secara bertahap, dari hasil tersebut diambil kesimpulan tentang perlu tidaknya melakukan siklus berikutnya.

Penelitian ini dilakukan dalam dua siklus. Setiap siklus terdiri dari empat tahap, yakni tahap perencanaan, tahap pelaksanaan/tindakan, tahap pengamatan dan tahap refleksi. Pelaksanaan untuk setiap siklus masing-masing siklus dilaksanakan 2 kali pertemuan.

Teknik pengumpulan data dalam penelitian ini adalah teknik observasi dan teknik tes. Observasi adalah kegiatan pengamatan atau pengambilan data untuk melihat bagaimana proses pembelajaran bahasa Jerman berlangsung di kelas. Observasi dilaksanakan bertujuan untuk mengamati pelaksanaan kegiatan atau aktivitas guru dan siswa serta melihat hambatan siswa dan mencatat pada lembar observasi. Sedangkan tes adalah alat atau prosedur yang digunakan dalam mengukur dan menilai. Tes diberikan kepada siswa untuk kemudian dikerjakan. Tes digunakan untuk mengetahui hasil dari kegiatan pembelajaran yang telah dilaksanakan. Tes 
diberikan pada setiap akhir siklus. Untuk mendapatkan data menulis kalimat bahasa Jerman.

Teknik analisis data dilakukan dengan menggunakan dua pendekatan yaitu kualitatif dan kuantitatif. Data proses pembelajaran dianalisis dengan menggunakan pendekatan kualitatif, sedangkan data hasil belajar dianalisis dengan menggunakan pendekatan kuantitatif. Data kualitatif berupa informasi suasana kelas (perhatian, antusias dalam belajar) yang di peroleh melalui observasi. Data kuantitatif yang berupa tes dianalisis menggunakan rerata, sehingga dapat diketahui peningkatan siswa dalam keterampilan menulis kalimat bahasa Jerman.

\section{HASIL DAN PEMBAHASAN}

Berdasarkan data lembar observasi siswa siklus I pada tabel di atas, maka dapat diketahui bahwa:

1. pada pertemua 1 siswa yang aktif membaca selintas dengan cepat materi tentang die Schule dengan lafal yang tepat sebanyak 12 orang dan siswa yang tidak aktif sebanyak 25, sedangkan pada pertemuan 2 siswa aktif 25 orang dan 12 orang siswa tidak aktif;

2. siswa antusias memperhatikan penjelasan guru sebanyak 23 orang dan siswa yang tidak aktif berjumlah 14 orang pada pertemuan 1, sedangkan pada peretemuan ke-2 siswa aktif 34 orang dan tidak aktif berjumlah 3 orang;

3. pada pertemuan 1 siswa yang membaca secara aktif sambil memberikan tanggapan terhadap apa yang telah dibaca dan menjawab pertanyaan sebanyak 10 orang dan siswa yang tidak aktif sebanyak 27 orang, sedangkan pada pertemuan ke-2 siswa aktif 15 orang dan yang tidak aktif 22 orang;
4. siswa yang aktif menghafal dan mengingat pelajaran serta mencoba memecahkan masalah dari informasi yang diberikan oleh guru dengan yang telah diketahui melalui bahan bacaan sebanyak 5 orang dan yang tidak aktif 32 orang pada pertemuan 1 . Sedangkan pada pertemuan ke-2 siswa aktif 9 orang dan 28 orang tidak aktif;

5. pada pertemuan 1 siswa yang aktif membaca kembali bahan bacaan jika masih belum yakin akan jawaban yang telah dibuat sebanyak 29 orang dan yang tidak aktif 8 orang, sedangkan pada pertemuan ke-2 siswa aktif 32 dan tidak aktif 5 orang;

6. siswa yang aktif menanyakan hal-hal yang belum dipahami berjumlah 13 orang dan siswa yang tidak aktif 24 orang, sedangkan pada pertemuan ke-2 siswa aktif 31 dan tidak aktif 6 orang;

7. pada pertemuan 1 siswa yang aktif membuat kesimpulan pada akhir pembelajaran sebanyak 26 orang dan yang tidak aktif 11 orang, sedangkan pada pertemuan ke-2 siswa aktif 36 dan 1orang yang tidak aktif;

8. siswa yang aktif mereka-reka pertanyaan sebanyak 11 orang dan siswa yang tidak aktif 26 orang pada pertemuan 1, sedangkan pada pertemuan ke-2 siswa aktif 19 dan sebanyak 18 siswa yang tidak aktif.

Dari hasil tersebut dapat diketahui bahwa rata - rata siswa yang aktif selama proses pembelajaran berlangsung pada siklus I sebanyak 20,62 (55,72\%) sedangkan rata rata siswa yang tidak aktif $16,8(44,28 \%)$. Selanjutnya, berdasarkan data lembar observasi siswa siklus II pada tabel di atas, maka dapat diketahui bahwa: 
1. pada pertemua 1 siswa yang aktif membaca selintas dengan cepat materi tentang die Schule dengan lafal yang tepat sebanyak 34 orang dan siswa yang tidak aktif sebanyak 3, sedangkan pada pertemuan 2 siswa aktif 34 orang dan 3 orang siswa tidak aktif;

2. siswa antusias memperhatikan penjelasan guru sebanyak 26 orang dan siswa yang tidak aktif berjumlah 11 orang pada pertemuan 1, sedangkan pada peretemuan ke-2 siswa aktif 37 orang;

3. pada pertemuan 1 siswa yang membaca secara aktif sambil memberikan tanggapan terhadap apa yang telah dibaca dan menjawab pertanyaan sebanyak 16 orang dan siswa yang tidak aktif sebanyak 21 orang, sedangkan pada pertemuan ke- 2 siswa aktif 16 orang dan yang tidak aktif 21 orang;

4. siswa yang aktif menghafal dan mengingat pelajaran serta mencoba memecahkan masalah dari informasi yang diberikan oleh guru dengan yang telah diketahui melalui bahan bacaan sebanyak 21 orang dan yang tidak aktif 16 orang pada pertemuan 1 . Sedangkan pada pertemuan ke- 2 siswa aktif 26 orang dan 11 orang tidak aktif;

5. pada pertemuan 1 siswa yang aktif membaca kembali bahan bacaan jika masih belum yakin akan jawaban yang telah dibuat sebanyak 21 orang dan yang tidak aktif 16 orang, sedangkan pada pertemuan ke-2 siswa aktif 33 dan tidak aktif 4 orang;

6. siswa yang aktif menanyakan hal-hal yang belum dipahami berjumlah 22 orang dan siswa yang tidak aktif 15 orang, sedangkan pada pertemuan ke-2 siswa aktif 32 dan tidak aktif 5 orang;
7. pada pertemuan 1 siswa yang aktif membuat kesimpulan pada akhir pembelajaran sebanyak 19 orang dan yang tidak aktif 18 orang, sedangkan pada pertemuan ke-2 siswa aktif 36 dan 1 orang yang tidak aktif;

8. siswa yang aktif mereka-reka pertanyaan sebanyak 23 orang dan siswa yang tidak aktif 14 orang pada pertemuan 1, sedangkan pada pertemuan ke-2 siswa aktif 25 dan sebanyak 12 siswa yang tidak aktif.

Dari hasil tersebut dapat diketahui bahwa rata - rata siswa yang aktif selama proses pembelajaran berlangsung pada siklus I sebanyak $24,31(65,70 \%)$ sedangkan rata rata siswa yang tidak aktif 10,88 $(29,40 \%)$.

Berdasarkan hasil analisis kualitatif dan kuantitatif, pelaksanaan pembelajaran dengan menggunakan model pembelajaran Course Review Horay (CRH) dapat memberikan perubahan kepada siswa. Siswa sangat antusias mengikuti pembelajaran ini karena siswa bisa belajar sambil bermain. Model pembelajaran tersebut dikemas dalam bentuk games, jadi semua siswa tampak aktif di setiap pembelajaran. Keterampilan menulis siswa juga mengalami peningkatan dari siklus I ke siklus II. Selain itu perhatian siswa juga mengalami kemajuan. Tampak pada saat guru memberikan penjelasan, siswa terlihat aktif mengajukan beberapa pertanyaan kepada guru dan bersedia menjawab setiap pertanyaan yang diajukan oleh guru.

Selama pelaksanan siklus I, semangat, keaktifan dan perhatian siswa pada proses pembelajaran masih rendah. Sebagian besar masih bersifat pasif, siswa hanya duduk diam mendengarkan dan mengerjakan sesuai yang dijelaskan oleh guru. Sebagian besar siswa belum mampu mengerjakan tugas secara mandiri dan tampak beberapa siswa malas 
untuk mengikuti pelajaran. Pada saat guru sedang menjelaskan, siswa memanfaatkan waktu tersebut untuk bercakap - cakap dengan siswa lain atau teman sebangkunya. Bahkan ada beberapa siswa, yang memilih tidur, bermain HP dan ada juga yang mengerjakan tugas dari pelajaran lain.

Terkadang guru harus menegur dan mengarahkan siswa yang berbuat demikian untuk kembali fokus pada pelajaran yang sedang berlangsung dan tak jarang guru juga meninggikan suaranya atau bertindak lebih tegas lagi karena siswa yang sudah diberi beberapa kali teguran oleh guru masih melakukan hal yang sama.

Pada siklus II terjadi peningkatan yang sangat signifikan, dimana keaktifan dan perhatian siswa mulai mengalami peningkatan. Hal ini dapat dibuktikan dari 2 kali pertemuan pada siklus II, siswa datang tepat waktu untuk mengikuti pelajaran. Siswa yang mengalami kesulitan dalam pembelajaran sudah mulai mengeksperisikan dirinya dan tidak malu lagi untuk bertanya kepada guru. Perhatian dan keaktifan siswa dalam memahami materi semakin baik, hal ini tampak dari keseriusan siswa memperhatikan penjelasan dan arahan yang diberikan oleh guru. Terbukti dari hasil menulis kalimat sederhana, siswa tidak kesulitan lagi untuk menyusun kalimat sederhana dengan menggunakan model pembelajaran Course Review Horay $(\mathrm{CRH})$.

\section{KESIMPULAN}

Hasill tes keterampilan menulis kalimat bahasa Jerman siswa kelas X Bahasa dan Sastra 2 SMA dengan menggunakan model pembelajaran Course Review Horay (CRH) menunjukkan bahwa nilai rata - rata hasil tes siswa pada siklus I adalah 4,64 dengan persentase 66,28\%, kemudian pengalami peningkatan pada siklus II dengan nilai rata - rata 5,97 dengan persentase $85,28 \%$. Berdasarkan hasil penelitian tersebut, dapat disimpulkan bahwa penerapan model pembelajaran Course Review Horay (CRH) dapat meningkatkan keterampilan menulis kalimat sederhana bahasa Jerman siswa kelas X Bahasa dan Sastra 2 SMAN 5 Bulukumba menggunakan model pembelajaran Course Review Horay ( $C R H)$.

\section{DAFTAR PUSTAKA}

Amalia, mutia nur. 2014. Penggunaan Model Pembelajaran Course Review Horay (CRH) untuk Meningkatkan Hasil Belajar Siswa Pada Materi Luas dan Keliling Bangun Persegi dan Persegi Panjang (diakses dari http://repository.upi.edu pada tanggal 10 Februari 2017 pukul 19.00 WITA). Aqib, Zainal. 2015. Model-model, Media, dan Strategi Pembelajaran Kontekstual (Inovatif). Bandung: Yrama Widya.

Arikunto, Suharsimi, dkk. 2011. Penelitian

Tindakan Kelas. Jakarta: Bumi Aksara.

Fatmawati, Sri. Dkk. 2015. Desain Laboratorium Skala Mini Untuk Pembelajaran Sains Terpadu. Yogyakarta: Publisher.

Komaidi, Didik. 2011. Panduan Lengkap Menulis Kreatif. Yogyakarta: Sabda Media.

Mantasiah, R., Juffri, J., \& Yusri, Y. 2017. Keefektifan Model Pembelajaran Jaring Laba-Laba (Webbed) dalam Keterampilan Menulis Karangan Sederhana Bahasa Jerman. INSANI, 20(2).

Qalbi, U. N., Mantasiah, R., Jufri, J., \& Yusri, Y. 2017. Efektivitas Model Pembelajaran Kooperatif Tipe Teams 
Games Tournaments dalam

Keterampilan Menulis Bahasa Jerman

Siswa Kelas XII IPA SMA Negeri 1

Bontonompo Kabupaten Gowa.

INSANI, 20(1).

Revika. 2016. Penerapan Model Course Review Horay (CRH) untuk Meningkatkan Hasil Belajar Pada Mata Pelajaran Sejarah Siswa Kelas XI I (diakses dari http://digilib.unila.ac.id pada tanggal 04 Maret 2017 pukul 23.00 WITA).

Romadloni, A., \& Mantasiah, R. Intercultural approach in foreign language learning to improve students' motivation. Senior Editors, 61.

Ruhiyat, Dyah Paradhita. 2014. "Model Pembelajaran Course Review Horay untuk Meningkatkan Penguasaan Nomina Bahasa Jerman". (diakses dari http://repository.upi.edu pada tanggal 10 Februari 2017 pukul 19.00 WITA).

Sulistiyanti, Vicalia. 2012. Pengaruh Model Pembelajaran Course Review Horay (CRH) Terhadap Pencapaian
Kompetensi Bekerja Secara Tim Mata Pelajaran Pelayanan Prima di SMKN 2 Godean (diakses dari http://eprints.uny.ac.id pada tanggal 10 Februari 2017 pukul 19.00 WITA). Suprijono, Agus. 2012. Cooperative Learning Teori dan Aplikasi PAIKEM. Yogyakarta: Pustaka Pelajar.

Taniredja, Tukiran. Faridli, Miftah. Harmianto Sri. 2015. Model-model Pembelajaran Inovatif dan Efektif. Bandung: Alfabeta.

Yusri, Y., Mantasiah, R., \& Jufri, J. 2018. The Use Of Two Stay Two Stray Model in English Teaching to Increase Student's Learning Outcome. Journal Of Advanced English Studies, 1(1), $39-43$.

Jufri, J. 2007. Metode Penelitian Bahasa. Sastra dan Budaya

Jufri, J., 2017. Strategi Pembelajaran Bahasa. Qudus, M. and Yusri, Y., 2017. Keefektifan Penggunaan Metode Audio Lingual dalam Pembelajaran Kemampuan Menyimak Bahasa Jerman. INSANI, 20(2). 